\title{
KŪNO KULTŪROS ŽINIŲ POVEIKIS GIMNAZIJOS MOKINIŲ FIZINIAM PARENGTUMUI
}

\author{
Vincentas Blauzdys, Audronius Vilkas \\ Vilniaus pedagoginis universitetas, Vilnius, Lietuva
}

\begin{abstract}
Vincentas Blauzdys. Socialinių mokslų daktaras. Vilniaus pedagoginio universiteto Kūno kultūros teorijos katedros docentas. Mokslinių
\end{abstract} tyrimų kryptis - mokinių fizinis ugdymas bendrojo lavinimo vidurinèje mokykloje, gimnazijoje.

\section{SANTRAUKA}

Lietuvos visuomené pamažu iš pramoninio lygmens pereina Ł̌žiniu amžiu. Šis perèjimas neišvengiamai susijęs su gyvenimo būdo, žmoniu santykiu kaita. Ne vien materialiniu vertybiu gausinimas, o ypač intelektine kūryba bei žiniomis grindžiama veikla jau veda ir vis aktyviau ves í prieki dabartinę šalies visuomenę. Šiame sparčiai kintančiu technologiju amžiuje mokinys atranda daugiau veiklos sričiu, labiau vertina intelektinę veikla ir gebejjimus. Didele mokiniu dalis mažiau laiko ir pastangu skiria fizinei veiklai, ypač sportavimui. Yra mokiniu, kurie praktikuoja fizine saviugda, bet ne visi turi reikiamu žiniu, aiškius sportavimo tikslus ir motyvus, t. y. sqmoninga kryptingos ir tikslingos fizinès veiklos pagrindimq. Taigi atsiranda kūno kultūros žiniųoptimalaus turinio, ju poveikio squmoningam supratimui ir fiziniam parengtumui paieškos problema.

Tyrimo tikslas - ištirti trečios gimnazijos klasès abieju lyčiu mokiniu nuomonę apie kūno kultūros žinias ir ju poreiki per kūno kultūros pamokas bei eksperimentu pagristi šiu žiniu poveiki tiriamuju gimnazistu fizinio parengtumo kaitai.

Pedagoginis eksperimentas atliktas vienos Vilniaus gimnazijos penkiose trečiose klasèse. Penkis mènesius tirtos 58 merginos ir 35 vaikinai. Eksperimento pradžioje ir pabaigoje tiriamieji apklausti raštu, 5 testais fiksuotas ju fizinis parengtumas. Be iprastu kūno kultūros žiniu teikimo per kūno kultūros pamokas dviejose eksperimentinio poveikio klasése dar papildomai vestos 4 teorinès kūno kultūros pamokos sausio ir vasario mènesiais (kas antra savaitę). Per pirmas dvi pamokas nagrinètas krepšinio ir tinklinio, per kitas dvi-gimnastikos sporto šaku istorija ir klasifikavimas, aptarta ju nauda mokiniui. K grupess klasèse atskiru teoriniu pamoku nebuvo. Be to, prieš ar po sportiniu žaidimu, gimnastikos pratimu, lengvosios atletikos rungčiu abieju grupiu tiriamiesiems buvo teikiama šiek tiek žiniu (2-3 min) apie judesiu mokomaja paskirti, ju biomechaninę struktūra, socialinę užduočiu reikšmę.

Nustatytas skirtumo tarp mokiniu atsakymu patikimumas. Grupiu aritmetiniu fizinio parengtumo rodikliu skirtumas ivertintas pagal Stjudento (t) kriteriju.

Tyrimo rezultatai rodo, kad prieš tyrima ir po jo daugiau nei pusé abieju grupiu tiriamuju buvo ir liko tos nuomonès, kad atskiros teorinès kūno kultūros pamokos nereikalingos. Jiems atrodè, kad turimu sporto šaku ir sveikatinimo žiniu pakanka, nes ir taip jomis retai pasinaudoja. Dauguma mokiniu nepageidavo kūno kultūros vadovèlio. Po eksperimentinio poveikio labiau pagerèjo merginu, o ne vaikinu fizinis parengtumas: dalis abieju grupiu tiriamuju viršijo Lietuvos kūno kultūros išsilavinimo standartu lygmeni.

Apibendrinant galima teigti, kad mokiniu kūno kultūros žinios yra prastos ir ju apimties jie nenori plèsti. Būtina ieškoti mokiniams artimesniu temu ir daugiau žiniu pradèti teikti jau žemesnése klasèse. Papildomos sporto šakos žinios nedaug pagerino tiriamuju fizini parengtuma.

Raktažodžiai: kūno kultūros žinios, mokiniu fizinis parengtumas, ju kaita.

\section{IVADAS}

$\mathrm{E}$ uropos demokratinè edukologija jau suvokè: klasikinès žmogaus ugdymo paradigmos vidiniai prieštaravimai yra pasiekę toki lygi, kad ja grindžiamas ugdymas nebegali tenkinti individo, visuomenès poreikių. Europoje susiklosčiusi situacija veikia ir Lietuvos švietimą (Barkauskaitè, 1997; Bitinas, 2000; Blauzdys, 2000). Dabar žinių visuomenèje mokykla, joje dirbantys mokytojai, turètų būti tarpininkai tarp mokinių ir jų aplinkos (Rajeckas, 1999). Todèl svarbu išugdyti poreiki mokytis, nes tik šitaip suvoksime nuolat besikeičianti pasauli (Rogers, 1965). Dabartinejje bendrojo lavinimo mokykloje žinių teikia visi dèstomi mokomieji dalykai, kartu ir kūno kultūra. Siekiama, kad mokinys, igydamas žinių, geriau suvoktų ugdymo, sveikatinimo, taikomają ir sportinę mokyklinès kūno kultūros funkcijas. Prasmingai parinktos kūno kultūros funkcijų naujovès skatintų domètis ir sąmoningiau fiziškai ugdytis pačiam mokiniui. Deja, tam prie- 
laidų yra mažai. I. J. Zuozienès (1998), K. Kardelio, S. Kavaliausko, V. Balzerio (2001) tyrimai rodo, kad tiek tarybiniu laikotarpiu, tiek atkūrus šalies nepriklausomybę mokinių kūno kultūros teorinis rengimas buvo ir yra tik deklaratyvaus pobūdžio: per kūno kultūros pamokas mokytojai labiau orientuoja berniukus lavinti fizines ypatybes, mergaites - siekti sveikos gyvensenos. Taip siaurinamos kūno kultūros žinios. Atsižvelgdamas i prastą mokinių teorini pasirengimą, V. Blauzdys (2002) pažymi, kad viena iš mokinio fizinio ugdymo paskirčiu — teikti, plèsti, apibendrinti svarbiausias valstybiniuose kūno kultūros standartuose pateiktas žinias: apie mokinio sveikatą, judesiu kultūrą, motorinius gebejjimus (kaip asmens vertybių sankaupa), jų savitarpio ryšius, atskleidžiančius fizinio ugdymosi dèsningumus.

Žinių poveikis formuojant teigiamą gimnazijos mokinių požiūrị i fizini ugdymąsi, sąmoningą jo prasmès suvokimą nèra išsamiai tirtas. Tą, matyt, lèmè nepakankamas pačių kūno kultūros mokytojų žinių lygis, tradiciškai susiklostęs mokytojų ir mokinių abejingumas teoriniam rengimui, dažnai prastos pamokų sąlygos žinioms teikti (nèra kūno kultūros vadovèlio, tinkamų patalpų ir kt.). Todèl svarbu išsiaiškinti, ar suteiktos sporto šakos žinios gali iš esmès pakeisti dabartinių paskutinès gimnazijos pakopos mokinių požiūrị i fizini ugdymąsi. Kyla ir kūno kultūros žinių optimalaus turinio, jų poveikio sąmoningam supratimui ir fiziniam parengtumui paieškos problema.

Tyrimo tikslas - ištirti trečios gimnazijos klasės abiejų lyčių mokinių nuomonę apie kūno kultūros žinias ir jų poreiki per kūno kultūros pamokas bei eksperimentu pagrịsti šių žiniu poveiki trečios klasės gimnazisčių ir gimnazistų fizinio parengtumo kaitai.

Tyrimo objektas - trečios gimnazijos klasès mokinių kūno kultūros žinių poreikis ir poveikis.

\section{TYRIMO METODAI IR TIRIAMIEJI}

Pedagoginis eksperimentas vyko 2003 metu sausio-gegužès mènesiais vienos Vilniaus gimnazijos trečiose klasėse. Atsitiktiniu būdu parinktos dvi eksperimentinès (E) ir trys kontrolinès $(\mathrm{K})$ klasès. E grupès klasėse tirti pagrindinès medicininès fizinio pajègumo grupès 21 mergina ir 13 vaikinu bei $\mathrm{K}$ grupés klasiu 37 merginos ir 22 vaikinai. Parengiamosios ir specialiosios medicininiu fizinio pajègumo grupių mokiniai pagal išgales dalyvavo eksperimente, bet jų tyrimo duomenys nebuvo apibendrinami.

Eksperimento metu sausio ir vasario mènesiais (kas antrą savaitę) E grupès klasèse vestos keturios teorinès kūno kultūros pamokos. Per pirmas dvi pamokas nagrinètas krepšinio ir tinklinio, per kitas dvi - gimnastikos sporto šaku istorija ir klasifikavimas, aptarta jų nauda mokiniui. $\mathrm{K}$ grupès klasèse atskirų teorinių pamokų nebuvo. Be to, prieš ar po sportinių žaidimų, gimnastikos pratimų, lengvosios atletikos rungčių abiejų grupių tiriamiesiems buvo teikiama šiek tiek žiniu ( $2-3 \mathrm{~min}$ ) apie judesiu mokomają paskirtị, jų biomechaninę struktūrą, socialinę užduočių reikšmę.

Eksperimento pradžioje ir pabaigoje tiriamieji raštu apklausti anketų metodu. Išsiaiškinta kūno kultūros žinių svarba ir jų poveikis III gimnazijos klasès mokinių fiziniam ugdymuisi. Po pedagoginio eksperimento žodžiu apklausti (interviu metu) du kūno kultūros pamokas $\mathrm{E}$ ir $\mathrm{K}$ grupių klasėse vedę mokytojai. Sužinota, kokia jų nuomonè apie kūno kultūros žinių svarbą ir poveikí abiejų lyčių tiriamiesiems.

Fiziniam parengtumui nustatyti naudoti Eurofito (2002) ir kiti testai bei atitinkama metodika:

1. Staigiajai jeggai matuoti - šuolis $\mathfrak{i}$ tolị iš vietos $(\mathrm{cm})$.

2. Lankstumui - „Sèstis ir siekti““ $(\mathrm{cm})$.

3. Rankų raumenų statinei ištvermei - kybojimas sulenktomis rankomis ant skersinio (s).

4. Vikrumui $-10 \times 5 \mathrm{~m}$ bejgimas šaudykle (s).

5. Statinei pusiausvyrai - stovèsena ant vienos kojos (s). Testas aprašytas P. Lechovičiaus (2000). Tiriamasis turèjo atsistoti ant vienos jam patogesnès kojos. Kitą koją sulenkti ir patraukti $\mathfrak{i}$ šali, priglausdamas pèda prie pirmos kojos kelio. Rankas turejjo uždèti ant liemens ir užsimerkti. Kai tiriamasis sujuda, atsimerkia, moja rankomis ar paleidžia jas nuo liemens - testas baigiamas. Testas atliekamas du kartus. Fiksuojamas geriausias bandymas, bet trunkantis ne ilgiau kaip $30 \mathrm{~s}$.

\section{REZULTATAI}

Norint papildyti kūno kultūros pamoką žiniomis, reikia žinoti, kiek jos mokiniams reikalingos ir naudingos, kokių trūksta.

Pokalbiai su trečios gimnazijos klasès 58 merginomis ir 35 vaikinais, su dviem kūno kultūros pamokas jiems vedusiais mokytojais atskleide, kad nemažai daliai tiriamujų trūksta sporto šakų ir 


\begin{tabular}{|c|c|c|c|c|c|c|c|}
\hline \multirow{11}{*}{$\begin{array}{l}1 \text { lentelè. Merginų } \\
\text { fizinio parengtumo } \\
\text { rezultatai prieš eks- } \\
\text { perimentą ir po jo }\end{array}$} & Eil. Nr. & Testas & Grupès & I tyrimas & II tyrimas & Poslinkis & $\begin{array}{l}\mathrm{P} \\
\mathrm{E}-\mathrm{K}\end{array}$ \\
\hline & \multirow[t]{2}{*}{1.} & \multirow[t]{2}{*}{ Šuolis $\mathfrak{i}$ toli iš vietos, $\mathrm{cm}$} & $E n=21$ & $173,19 \pm 1,61$ & $175,33 \pm 1,43$ & 2,14 & \multirow{2}{*}{$\mathrm{p}<0,05$} \\
\hline & & & $\mathrm{Kn}=37$ & $166,32 \pm 1,59$ & $167,14 \pm 1,68$ & 0,82 & \\
\hline & \multirow[t]{2}{*}{2.} & \multirow[t]{2}{*}{ „Sèstis ir siekti“, $\mathrm{cm}$} & $\mathrm{E}$ & $24,76 \pm 0,76$ & $25,43 \pm 0,70$ & 0,67 & \\
\hline & & & $\mathrm{K}$ & $23,43 \pm 0,62$ & $24,53 \pm 0,69$ & 1,10 & \\
\hline & \multirow[t]{2}{*}{3.} & \multirow{2}{*}{$\begin{array}{l}\text { Kybojimas sulenktomis } \\
\text { rankomis, } \mathrm{s}\end{array}$} & $\mathrm{E}$ & $6,98 \pm 1,04$ & $8,79 \pm 1,17$ & 1,81 & \multirow{2}{*}{$\mathrm{p}<0,05$} \\
\hline & & & $\mathrm{K}$ & $4,56 \pm 0,52$ & $4,66 \pm 0,56$ & 0,10 & \\
\hline & \multirow[t]{2}{*}{4.} & \multirow[t]{2}{*}{ Stovėsena ant vienos kojos, $\mathrm{s}$} & $\mathrm{E}$ & $6,71 \pm 0,77$ & $12,00 \pm 0,99$ & 5,29 & \multirow{2}{*}{$\mathrm{p}<0,01$} \\
\hline & & & $\mathrm{K}$ & $5,92 \pm 0,34$ & $7,39 \pm 0,45$ & 1,47 & \\
\hline & \multirow[t]{2}{*}{5.} & \multirow[t]{2}{*}{$10 \times 5$ bègimas, $\mathrm{s}$} & $\mathrm{E}$ & $21,12 \pm 0,28$ & $20,82 \pm 0,27$ & 0,3 & \\
\hline & & & $\mathrm{K}$ & $21,34 \pm 0,20$ & $21,28 \pm 0,20$ & 0,06 & \\
\hline
\end{tabular}

2 lentelè. Vaikinų fizinio parengtumo rezultatai prieš eksperimentą ir po jo

Pastaba. $\Delta-$ patikimas skirtumas tarp E ir K grupiu mokiniu rezultatu $(\mathrm{p}<0,05)$.

\begin{tabular}{|c|l|c|c|c|c|}
\hline Eil. Nr. & \multicolumn{1}{|c|}{ Testas } & Grupés & I tyrimas & II tyrimas & Poslinkis \\
\hline \multirow{2}{*}{1.} & \multirow{2}{*}{ Suolis i toli iš vietos, cm } & $\mathrm{En}=13$ & $242,69 \pm 3,14$ & $242,31 \pm 3,06$ & 0,38 \\
\cline { 3 - 6 } & & $\mathrm{Kn}=22$ & $239,23 \pm 1,68$ & $238,77 \pm 2,30$ & 0,46 \\
\hline \multirow{2}{*}{2.} & \multirow{2}{*}{ Sėstis ir siekti“, cm } & $\mathrm{E}$ & $28,77 \pm 1,03$ & $28,92 \pm 1,08 \boldsymbol{\Delta}$ & 0,15 \\
\cline { 3 - 6 } & & $\mathrm{K}$ & $24,05 \pm 0,83$ & $24,50 \pm 0,97$ & 0,45 \\
\hline \multirow{2}{*}{3.} & \multirow{2}{*}{ Kybojimas sulenktomis rankomis, s } & $\mathrm{E}$ & $36,54 \pm 1,72$ & $37,15 \pm 2,08$ & 0,61 \\
\cline { 3 - 6 } & & $\mathrm{K}$ & $33,59 \pm 1,84$ & $37,00 \pm 2,07$ & 3,41 \\
\hline \multirow{2}{*}{4.} & \multirow{2}{*}{ Stovėsena ant vienos kojos, s } & $\mathrm{E}$ & $15,69 \pm 1,23$ & $15,46 \pm 1,29$ & 0,23 \\
\cline { 3 - 6 } & & $\mathrm{K}$ & $12,73 \pm 0,97$ & $15,73 \pm 1,22$ & 3,00 \\
\hline \multirow{2}{*}{5.} & \multirow{2}{*}{$10 \times 5$ bėgimas, s } & $\mathrm{E}$ & $17,14 \pm 0,29$ & $17,02 \pm 0,26$ & 0,12 \\
\cline { 3 - 6 } & & & $17,47 \pm 0,19$ & $17,01 \pm 0,23$ & 0,46 \\
\hline
\end{tabular}

sveikatinimo žinių, daugelis nežino konkretesnès jų naudos sau ir nenori to žinoti. Eksperimento pradžioje per pirmą apklausa raštu net $66,6 \% \mathrm{E}$ grupès merginu ir 53,8\% vaikinų, $45,9 \% \mathrm{~K}$ grupès merginu ir 54,5\% vaikinų buvo issitikinę, kad jiems nereikalingas teorinis kūno kultūros kursas. Po eksperimento taip manančių E grupès merginu padaugejjo net iki 90,5\% $(\mathrm{p}<0,05)$, vaikinu — iki $61,5 \%$. K grupès tiriamujų nuomonè išliko beveik ta pati.

Tyrimo pradžioje net $80,9 \% \mathrm{E}$ ir $62,2 \% \mathrm{~K}$ grupès merginu, $84,6 \% \mathrm{E}$ ir $81,8 \% \mathrm{~K}$ grupès vaikinų teigè, kad jiems kūno kultūros vadovèlis nereikalingas (Lietuvos 5-12 klasių mokiniai kūno kultūros vadovèlio neturi). Po eksperimento daugiau abiejų grupių gimnazisčių jau pageidavo kūno kultūros vadovèlio (E klasėse padaugejo $9,5 \%, K-13,5 \%$ tokių tiriamuju). Tačiau kūno kultūros vadovèlio jau nenorèjo nè vienas $\mathrm{E}$ grupès vaikinas, o kad jis reikalingas, atsake tik $13,6 \% \mathrm{~K}$ grupès vaikinu. Pirmos apklausos metu $61,9 \%$ E klasiu gimnazisčių ir 53,8\% gimnazistų, $56,7 \% \mathrm{~K}$ klasiu merginu ir $72,7 \%$ vaikinu pakako turimu kūno kultūros žiniu. Po eksperimentinio poveikio taip teigiančiu $\mathrm{E}$ grupès merginu sumažèjo iki 52,4\%, o K grupès merginu — iki 43,2\%. Tokių E grupès vaikinu jau buvo šiek tiek daugiau $(69,2 \%)$, o $\mathrm{K}$ grupès vaikinų net patikimai $(\mathrm{p}<0,05)$ sumažèjo iki 27,3\%.
Kūno kultūros žinios yra taikomojo pobūdžio. Todèl svarbu ne tik suvokti žiniu naudą, bet panaudoti jas mankštinantis. Eksperimento pradžioje $52,4 \% \mathrm{E}$ ir $48,6 \% \mathrm{~K}$ grupès gimnazisčiu buvo isitikinusios, kad jos turimas žinias panaudoja per kūno kultūros pamokas. Antros apklausos metu po gautų kūno kultūros žinių 9,5\% mažiau tirtų E grupès ir $8,1 \% \mathrm{~K}$ grupès merginų teigè, kad igytas žinias panaudoja pamokų metu. Šiuo klausimu labiau išryškejo tiriamujų lyties savitumai: pradžioje $46,1 \%$ E grupès vaikinų teigè, kad kūno kultūros žiniomis pasinaudoja, lygiai tiek pat galvojo, kad iš šių žinių neturi naudos. $68,2 \%$ $\mathrm{K}$ grupès gimnazistų teige, kad igytas žinias panaudoja, o $27,2 \%$ — kad iš jų neturi naudos. Po eksperimento tiek pat $\mathrm{E}$ grupès vaikinu teigè pasinaudoję igytomis žiniomis, o K grupès - tik $31,8 \%(\mathrm{p}<0,05)$.

I klausimą, ar kūno kultūros žinios yra naudingos, pirmos apklausos metu teigiamai atsake tik $52,4 \% \mathrm{E}$ ir $45,9 \% \mathrm{~K}$ grupių merginu. Po antro tyrimo tuo issitikinusių buvo šiek tiek mažiau $\mathrm{E}$ grupès merginų. Eksperimentinès programos pradžioje apie kūno kultūros žinių naudą žinojo daugiau vaikinų nei merginų: $61,5 \% \mathrm{E}$ ir $81,8 \% \mathrm{~K}$ grupès vaikinų. Po antro tyrimo šią naudą jau suvokè mažiau — tik $46,1 \% \mathrm{E}$ ir $63,7 \% \mathrm{~K}$ grupès vaikinų.

Paaiškèjo, kad šio amžiaus tiriamiesiems kūno grožis yra svarbus saviraiškos būdas. Todèl abie- 
jų lyčių mokiniams labiausiai rūpèjo žinios apie gražaus kūno formavimą ir sveikatos stiprinima. Mažiau juos domino mūsų teikiamos žinios apie sporto šakų mokymosi techniką, varžybų taisykles. Per eksperimentini laikotarpi statistiškai patikimai $(\mathrm{p}<0,05)$ padidejo tik E grupès gimnazistų sveikatos stiprinimo, o $\mathrm{K}$ grupès vaikinu gražaus kūno formavimo ir sporto šaku poveikio organizmui žinių poreikis.

Ugdant teigiamą požiūrị i kūno kultūrą, poreiki gauti žinių apie savo fizinę būklę, norą stiprinti savo fizini pajègumą, tikslinga nustatyti ir įvertinti fizini parengtuma. Gauta informacija gali skatinti ugdytinius domètis savo fizinèmis ypatybèmis, ju lavinimo priemonèmis ir būdais.

Palyginus E ir K grupių gimnazisčiu ir gimnazistų fizinio parengtumo rodiklius eksperimento pradžioje nustatyta, kad E grupès merginos statistiškai patikimai toliau šoko į toli iš vietos $(\mathrm{p}<0,01)$, o vaikinai buvo lankstesni $(\mathrm{p}<0,05)$ už K grupès tiriamuosius. Po eksperimento $\mathrm{E}$ grupès merginų rezultatu pranašumas padidejo. Statistiškai patikimai skyrèsi šuolio ị toli iš vietos $(\mathrm{p}<0,05)$, kybojimo sulenktomis rankomis $(\mathrm{p}<0,05)$, stovésenos ant vienos kojos $(\mathrm{p}<0,01)$ rezultatai (1 lent.).

Iš 2 lentelès matyti, kad po eksperimentinio poveikio $E$ grupès vaikinu šuolio i toli iš vietos ir stovèsenos ant vienos kojos, o $\mathrm{K}$ grupès tiriamuju šuolio į tolį iš vietos rezultatai nepagerejo. Vis dèlto E grupès gimnazistų dviejų testų (šuolio į tolị iš vietos bei „Sèstis ir siekti“) rezultatai buvo šiek tiek geresni už atitinkamus $\mathrm{K}$ grupès gimnazistų rodiklius. Kitų testų rezultatai buvo panašūs.

\section{REZULTATU APTARIMAS}

Apibendrinant gimnazijos trečios klasès mokinių anketinès apklausos ir kūno kultūros mokytojų interviu rezultatus galima teigti, kad tiriamiesiems teorinès kūno kultūros pamokos buvo naujovè ir penkių mènesių nepakako norint pakeisti susidariusią nepalankią nuomonę apie kūno kultūros žiniu naudą. Papildomas vadovèlis tiriamuosius gąsdintú. Vis dèlto po eksperimento šiek tiek padaugejo merginų, manančių, kad kūno kultūros vadovèlis padètú konkretinti mokiniui reikalingas žinias ir skatintų savarankiškai domètis rūpimais dalykais.

I. J. Zuozienès (1998), K. Kardelio ir kt. (2001), mūsų tirtų mokytojų nuomone, mokiniai kūno kultūrą vertina kaip nereikšmingą mokomaji dalyką, kurio žinios jiems nėra tokios svarbios, todèl dauguma nepageidauja pamokų, skirtų teoriniam dalyko gilinimui. Atliktas tyrimas rodo, kad pokalbiai apie kūno kultūros naudą labiau pakeitè E grupès merginų nuomonę apie kūno kultūros pamokų prasmę (reikšmę joms). K grupès gimnazisčių nuomonè šiuo klausimu pakito mažai. Be to, per eksperimentini laikotarpi šiek tiek sumažèjo E grupès vaikinų, teigiančių, kad jiems kūno kultūros pamokos yra prasmingos. Šiai nuomonei galèjo turèti itakos susiformavusi tradiciné nuostata, kad pagrindini kūno kultūros pamokų turinị turi sudaryti psichomotorinè veikla judejimo džiaugsmui žadinti, fizinio aktyvumo poreikiui tenkinti, psichinei itampai po mokymosi mažinti ir nenoras papildomai mokytis. İrodyta, kad kūno kultūros žiniu poreikị ir lygi lemia mokinių domejjimasis kūno kultūros mokomuoju dalyku (Zuozienè, 1998; Kardelis ir kt., 2001; Mikaitienè, Volbekienė, 2002). Deja, Lietuvos bendrojo lavinimo mokykluc mokinių tyrimai rodo žemą netgi elementariausių kūno kultūros žinių lygi, o mokiniai yra mažai susipažinę net su tomis sporto šakomis, kurios įeina i mokyklinę kūno kultūros programą jau nuo V klasès (Rajeckas, 1999; Blauzdys, 2000). Kuo vyresni mokiniai, tuo labiau mažèja palankus požiūris i kūno kultūros žinias, daugèja neigiamai vertinančių šio dalyko pamokas.

Dabartinèje šalies bendrojo lavinimo mokyklų ugdymo kaitos sistemoje į mokymąsi žiūrima kaip í veiklą, kurios metu žmogus plètoja ne tik savo žinias, gebejjimus, ypač vertybes, patirtị, bet ir ugdo savitą požiūri, mokosi kritiškai mąstyti. Poreikis kyla ne tik dèl išorès poveikio, bet ir dèl asmenybès vidiniu interesų. Tada individas pats sau kelia mokymosi tikslus. Čia svarbus ir kūno kultūros mokytojo vaidmuo - ne tik kaip žinių šaltinio, bet ir skatintojo, tarpininko tarp mokinio ir informacinès aplinkos.

Tiriamuju fizinio parengtumo rezultatai buvo palyginti su Eurofito referencinių lenteliu atitinkamais duomenimis. Nustatyta, kad tik E grupès gimnazisčių staigiosios jègos (šuolio į tolị iš vietos) ir vikrumo $(10 \times 5 \mathrm{~m})$ rezultatu vidurkiai eksperimento pradžioje ir pabaigoje buvo didesni už atitinkamus mūsų šalies merginų Eurofito testo vidurkius. Kiti abiejų grupių merginų pirmo ir antro tyrimų rezultatai buvo šiek tiek prastesni. E grupès vaikinu lankstumo, abieju grupiu gimnazistų staigiosios jègos ir vikrumo rezultatu vidurkiai tyrimo pradžioje ir pabaigoje buvo didesni už atitinkamus Eurofito rezultatų vidurkius, nors eksperimento poveikio vaikinų šuolio i tolị 
rezultatu vidurkis nepagerejo. Eksperimento metu buvo laikomasi nuomonès, kad dažnai pasitaikantis griežtas, sunkus, didelių fizinių ir psichinių pastangu reikalaujantis fizinio ugdymo modelis skatina negatyvią fizinio aktyvumo motyvacija (Feingold and Barrete, 1991; Blauzdys, 1999; Rawland, 1999). Mokiniai efektyviai fiziškai ugdomi tuomet, kai per kūno kultūros pamokas patirtas mokymosi džiaugsmas sužadina fizinio aktyvumo poreiki, moko kritiškai ir konstruktyviai mąstyti, sportuoti, socializuotis.

Mokiniu fizinis rengimas yra sudètingas procesas, o rezultatai sunkiai pasiekiami. Jų siektinas ribas rodo Lietuvos kūno kultūros išsilavinimo standartai (2003). Tyrimo metu abiejų grupių gimnazistai ir gimnazistès pasiekẻ šalies kūno kultūros išsilavinimo standartų bendrojo kurso, o dalis tiriamuju — išplèstinio kurso normatyvus ir viršijo Eurofito fizinio parengtumo rezultatų vidurkius. Eksperimento metu nebuvo reikalaujama iš mokinių dideliu fiziniu ir psichiniu pastangu, o stengtasi sudaryti sąlygas kiekvienam ugdytiniui tobulèti pagal poreikị. Atsižvelgta ir į tai, kad mokslo metu pabaigoje pastebimas mokinių nuovargis, pablogeja sveikata, fizinis ir protinis darbingumas. Perteikiant žinias ir atskleidžiant fizinio ugdymosi dèsningumus, buvo siekiama integruoti emocinius, intelektinius ir psichomotorinius mokymosi aspektus. Tai sudètingas procesas, reikalaujantis didelio atidumo, nuoseklumo net tik iš mokytojo, bet ir mokinio, nes keičiama veiksena bei mąstysena. Tyrimai rodo, kad šiandienineje bendrojo lavinimo mokykloje mokinys tampa vartotoju, kuris pats geba pasi- rinkti mokymosi metodus, mąstyti ir vertinti savo galimybes, priimti tinkamą sprendimą (Bitinas, 2000; Blauzdys, 2002). Galima prognozuoti, kad jau žemesnèse klasėse, glaudžiau bendradarbiaujant su kitų mokomujų dalykų mokytojais, atsižvelgiant i lyties skirtumus, pamažu didinant ne tik žiniu apimti, bet ir taikomaji, ypač socialini, ju pobūdi, labiau jas individualizuojant, sudarant salygas, kad pats mokinys tǔ žinių norètų, galima sulaukti palankesnio požiūrio ị kūno kultūros žinias, geresnio sportavimo sąmoningumo ir reguliavimo.

\section{IŠVADOS}

1. Eksperimento pradžioje atliktos trečios gimnazijos klasès mokinių ir kūno kultūros mokytoju apklausos rezultatai rodo, kad mokiniu sporto šakos ir metodinès kūno kultūros žinios yra prastos. Daugumos mokinių nuomone, jiems pakanka turimų kūno kultūros žinių ir todèl atskiros teorinès pamokos, vadovèlis jiems nereikalingi.

2. Po eksperimentinio poveikio tik daugiau nei pusę eksperimentinès grupés merginų ir du trečdalius vaikinų, mažiau nei pusę kontrolinès grupès merginu ir šiek tiek daugiau nei ketvirtadali vaikinų tenkino teikiamų kūno kultūros žinių apimtis. Todèl per kūno kultūros pamoką reikètų teikti kuo daugiau žinių.

3. Nustatyta, kad abiejų grupių ir lyčių tiriamujų fizinis parengtumas per penkis mènesius pakito nedaug. Papildomos sporto šakos žinios labiau pagerino eksperimentinio poveikio klasių merginų nei vaikinų fizini parengtumą.

\section{LITERATŪRA}

Barkauskaitè, M. (1997). Lietuvos švietimo reformos eigos tyrimai. Pedagogai ir mokiniai: požiūris i švietimo reformą. Švietimo studiju sqsiuvinis, 6-51.

Bendrosios programos ir išsilavinimo standartai. (2003). Vilnius: Švietimo aprūpinimo centras.

Bitinas, B. (2000). Ugdymo filosofija. Vilnius: Enciklopedija.

Blauzdys, V. (2000). Changes in the physical education teacher's school activity in the period of restored statehood of Lithuania. Lifanische Gesprache zur Padagogik, $2,199-205$

Blauzdys, V. (1999). Kaurpererziehung in Litaniscen Schulen. Litanische Gesrorache zur Pedagogik, 1, $181-185$.

Blauzdys, V. (2002). Naujoviška kūno kultūros pamoka: mokymo priemonè kūno kultūros specialybès studentams, magistrantams. Vilniaus: VPU.

Eurofitas. Fizinio pajègumo testai, metodika, Lietuvos moksleiviu fizinio pajegumo rezultatai. (2002). Parengè V. Volbekienè, S. Kavaliauskas. VIlnius: LSIC.

Feingold, R. and Barrete, G. (1991). Strategies for school fitness curricural modifications: And integrative model utilizing the superordinate goal theory. Sport and Physical Activity, 12, 54-59.

Kardelis, K, Kavaliauskas, S., Balzeris, V. (2001). Mokykline kūno kultūra: realijos ir perspektyvos: monografija. Kaunas: LKKA.

Lechovičius, R. (2000). Judesiu valdymas: samprata, vertinimas. Asmens sveikatos ugdymas: mokomoji knyga. Kaunas: KMU. P. 120-127.

Mikaitienè, G., Volbekienè, V. (2002). Stimulation of the students' physical self-education via creating efficiency class climate. Sport Science, 3 (29), 54-61.

Rajeckas, V. (1999). Requirements for the modern content of teaching at the secondary school. Pedagogics, 39, $15-25$.

Rawland, T. (1999). Exercise and Children's Health. Champaign IL: Human Kinetics.

Rogers, C. (1965). On Becoming a Person. Boston.

Zuozienè, I. J. (1998). Kūno kultūros ir sveikos gyvensenos žiniu ìtaka moksleiviu fiziniam aktyvumui: edukologijos daktaro disertacija. Kaunas: LKKA. 


\title{
INFLUENCE OF PHYSICAL TRAINING KNOWLEDGE ON PHYSICAL FITNESS OF GYMNASIUM STUDENTS
}

\author{
Vincentas Blauzdys, Audronius Vilkas \\ Vilnius Pedagogical University, Vilnius, Lithuania
}

\begin{abstract}
Lithuanian society is gradually going over the industrial age to the informational age. This transition is inevitably related to complex changes in the way of life and human relationships. Activities based not only on the increasing material values but also on the intellectual creation and knowledge is actively driving the society of the country forward. In this rapidly changing age of technologies students find more spheres of activity, they value intellectual activity and skills more. Thus the majority of students spend less time and effort on physical activity, especially sports. There are also students who practice physical self-education, but not all of them have the necessary knowledge, clear objectives and motives of engaging in sports, i. e. conscious foundation of targeted physical activity. Probably the knowledge of physical training should be relevant to the present of the student and designed for the future, correspond to his / her modern social and cultural level, and reasonably satisfy the needs and possibilities of students. Much knowledge of physical training can be provided by the teacher of physical training applying examples of physical training in the integration of subjects. This raises the issue of searching for optimal content of PT knowledge, its influence on the conscious perception and physical fitness of students.

Purpose of the work. This research is an attempt to analyze the opinion of the third year gymnasium students of both sexes about the knowledge of physical training and their needs in PT lessons, and determine the influence of this knowledge on the changes in the physical fitness of the gymnasium students who participated in the experiment.

Material and methods. The pedagogical experiment was carried out in five third-year classes of one Vilnius gymnasium. 58 girls and 35 boys were studied for five months. At the beginning and the end of the experiment the students were questioned in writing, and their physical fitness was recorded by 5 tests. Besides the ordinary presentation of physical training knowledge during PT lessons 4 additional theoretical PT lessons were held in two of the experimental groups. The first two lessons were devoted to the history and classification of basketball and handball, and the other two for gymnastics, as well as their benefit for the students. There were no theoretical lessons in the classes of group C. Besides, before or after the sports activities, gymnastics exercises or track-and-field events, some knowledge $(2-3 \mathrm{~min})$ on the educational purpose of movements, their biomechanical structure and the social significance of tasks was presented to the students in both groups. The credibility of the differences between the answers of students was established. The differences between the arithmetical indicators of physical fitness of the groups were evaluated according to Student's (t) criterion.

Results. Before and after the research, over half of the analyzed students from both groups were and remained of the opinion that separate theoretical PT lessons were not necessary. They thought that the knowledge they had of sports and healthy way of life was sufficient and they used it rarely. The majority of students did not want a PT course book. Physical fitness of girls improved more than that of boys after the experiment. Part of the students from both groups exceeded the level of physical training development standards in Lithuania.

Conclusions. The research showed that the knowledge of physical training of students was poor and they did not want to increase its scope. It is necessary to look for subjects closer to students and start presenting it in a larger scope already in lower classes. The acquired additional knowledge of sports did not improve students' physical fitness much.
\end{abstract}

Keywords: knowledge of physical training, students' physical fitness, their changeability.

Gauta 2006 m. rugsèjo 12 d.

Received on September 12, 2006

Priimta 2006 m. gruodžio 6 d.

Accepted on December 6, 2006
Audronius Vilkas

Vilniaus pedagoginis universitetas

(Vilnius Pedagogical University)

Studentu g. 39, LT-06316 Vilnius

Lietuva (Lithuania)

Tel +370 52607746

E-mail a.vilkas@vpu.lt 